\title{
Macrophyte Diversity and Biomass Productivity of Manikamaun Wetland, Muzaffarpur, North Bihar
}

\author{
Priyanka Gautam $^{1 *}$, Adita Sharma ${ }^{1}$, Poonam Prakash ${ }^{1}$ and Shivani Pathak ${ }^{2}$
}

${ }^{1}$ Department of Fisheries Resource Management, College of Fisheries, Dr. Rajendra Prasad Central Agricultural University, Dholi, Muzaffarpur, Bihar, India

2Department of Fisheries Resource Management, College of Fisheries Science, Veraval, Gujarat, India

*Corresponding author

\section{A B S T R A C T}

Keywords

Diversity,

Macrophytes,

Biomass,

Mannikamaun

\section{Article Info}

\section{Accepted:}

20 January 2021

Available Online:

10 February 2021
The current study was carried out in Manikamaun wetland located in North Bihar, where Macrophyte diversity and biomass estimation was observed from June 2019 to March 2020. A total of 24 species of macrophytes belonging to 15 families were recorded from the wetland. From the identified species, Hydrocharitaceae (3), Potamogetonacea (3), Poaecae and Cyperaceae ( 2 each) were found dominant. Biomass productivity of observed macrophytic plants was estimated, Aquatic macrophytes were categorized in 4 types, viza, Free-floating plants (40\%), Submerged (33\%), Rooted with floating leaves (25\%) and emergent (2\%). Maximum biomass was recorded in month of February $387.91 \mathrm{~g} / \mathrm{m}^{2}$ and minimum during the month of July $123.27 \mathrm{~g} / \mathrm{m}^{2}$, a total of $2541.88 \mathrm{~g} / \mathrm{m}^{2}$ of biomass was recorded from the maun. Among the various macrophyte species reported, highest biomass contributor was Eichhornia crassipes $1293.26 \mathrm{~g} / \mathrm{m}^{2}$, followed by Najas graminea (610.17 $\left.\mathrm{g} / \mathrm{m}^{2}\right)$, Nelembo nucifera $\left(562.75 \mathrm{~g} / \mathrm{m}^{2}\right)$, and Hydrilla verticellata $\left(221.24 \mathrm{~g} / \mathrm{m}^{2}\right)$.

\section{Introduction}

Macrophytes (aquatic vascular plants) are an essential component of wetland ecosystems and a diverse assemblage of macrophytes can increase habitat heterogeneity in a wetland (Cook, 1996; Keddy, 2000; Mitsch and Gosselink, 2000; Cronk and Fennessy, 2001). They are an incredibly important part of a primary growth and nutrient cycling aquatic ecosystem (Peakall and Burger, 2003). Aquatic plant diversity and distribution is closely related Linked to the system's environmental determinants (Moyle, 1945; Spence, 1967; Heegaard et al., , 2001). They create enormous biomass and play a vital role in the wetlands productivity and nutrient condition. "Where there are weeds, it is wetland" this was stated by Brij Gopal. This tells as that macrophytes are a crucial part of wetlands, macrophytes are aquatic plants. Freshwater macrophytes (higher vascular plants) play an imperative task in deciding the competitive essence of the water body and are known as the most competitive plant species and therefore the freshwater biomass reserve 
represents an immense opportunity for sustainable development (Westlake, 1975; Anand, 1986). Biomass refers to the mass of living species, comprising plants, animals, and microorganisms, or to cellulose, lignin, carbohydrates, fats, and proteins from a biochemical perspective. Biomass comprises all the plant tissues above and below ground, such as leaves, twigs, branches, boles, as well as grass roots of trees and rhizomes. Biomass is also recorded as a mass per unit area $\left(\mathrm{g} \mathrm{m}^{2}\right.$ or $\mathrm{Mg} \mathrm{ha}{ }^{1}$ ) and as a dry weight, typically (water removed by drying) (Houghton, 2005). The total amount of organic matter present in the plants in any ecosystem at a given time is referred to as the plant biomass. The determination of plant biomass is one of the most important criteria for the assessment of primary productivity. The aquatic macrophytes may produce large amounts of biomass comparable to the highly productive plants of the terresterial ecosystems (Reddy, 1984). Biomass typically contains only live content, unless otherwise mentioned. Many studies have been conceded in several researchers worldwide as well as India, relating to the primary productivity of aquatic macrophytes. Acharjee (2012) explored environmental research in the Brahmaputra Delta, Assam, and its productivity, Pathak et al., (2004) Hydrological characteristics of Uttar Pradesh's eighteen wetlands suggested their strong productive character. In this study a similar approach was made to study the diversity of the wetland macrophytes in Manikamuan in Bihar. Macrophytes area vital units required in maintain the ecological balance of wetlands. They are a major structural unit in construction of wetland.

\section{Materials and Methods}

\section{Study site}

Manikamaun is a freshwater wetlands, located in Mushari block in Muzaffarpur district which lies in North Bihar between latitude $25^{\circ} 54^{\prime} 00^{\prime \prime}$ to $26^{\circ} 23^{\prime} 00^{\prime \prime}$ and longitude $84^{\circ} 53^{\prime} 00^{\prime \prime}$ to $85^{\circ} 45^{\prime} 00^{\prime \prime}$. The water spread area is about 40 ha, and receives water mainly from precipitation and ground water. Seasonal fluctuation in the water level can be noticed throughout the year, water is utilized by local mainly for irrigation, washing cloths and fishing by local folks.

\section{Sampling methods}

Collection of macrophytes was done with the help quadrat of size $1 \mathrm{~m}^{2}$ made of PVC pipe on a monthly basis from June 2019 to March 2020. The sampling site was divided into three part, upper, middle and lower zone, quadrat was placed at randomly drawn point at the sampling site. Above ground macrpohytes samples were collected occurring within the quadrat frame. Sample collection was done manually, for freefloating and submerged plants were picked, where as for rooted macrophytes local fishermen were assist to dive and clip the macrophytes appearing within the frame. Collected samples were placed in a plastic bag and brought to labatory. Samples were gotten rid of attached animals, soil and other derbies then excess water was removed. Macrophytes were seggrated species wise for identification and estimation of biomass. Samples were first air dried and then put in hot air oven at $48 \mathrm{hr}$ at $80^{\circ} \mathrm{c}$.

\section{Results and Discussion}

In the present study, there were total 24 species of marcophytes identified, belonging to 18 families in Manikamaun. The recorded plants were grouped under different categories, viz. 3 species belonged to Freefloating, 4 species belonged to Rooted floating leaf, 8 species belonged to Submerged, and 9 species belonged to Emergent in Manikamaun. Hydrocharitaceae 
(3), Poaceae (3), Potamogetonceae (2) and Cyperaceae (2) family had major number of species occurring in them. Among the different type of macrophtyes based on the zone in which they were present in water, the highest numbers of macrophytes were recorded in emergent plants $(38 \%)$, followed by submerged (33\%), rooted-floating leave $(17 \%)$ and least in free-floating $(3 \%)$. Human interference for domestic purpose and other hydrological and biological factor might have attributed to the variation in the number of the macrophytic plants. Shah and Abbas (1979) reported 28 species in the river Ganga at Bhagalpur. Out of this total, 22 were emergents, 4 submerged species and 2 floating leaved species. Pammi and Jha (2016) reported 28 plant species in Muktapur maun, in which 12 were Emergent species, 5 rooted floating leaved, 5 free-floating and 2 submerged species. In a study of Waithou lake, Manipur, Devi, O.I. (1993) also reported 18 emergent, 5 free floating, 6 rooted with floating leaves and 6 submerged species, out of 35 species recorded in 1989 whereas 15 emergent species, 5 free-floating, 6 rooted with floating leaves and 6 submerged species were observed out of 32 species in 1990. Devi, K.I. (1997) in Utrapat Lake, Manipur reported the presence of 26 macrophytic species, out of which 11 were emergent, 6 submerged and 3 species each under the rooted floating leaf and free-floating categories (Fig. 1-3; Table 1 and 2).

For estimation of biomass 16 dominant macrophyte species were considered and species reporting very less biomass were catgerized as other species which included Glyceria maxima, Bacopa monnieri, Cortaderia selloana, Cyperus compressus, $C$. imbricatus, Cynodon dactylon. The macrophytic species showed noticeable variations in the biomass values and they attained their maximum values during different months of the year. Highest biomass was recorded from species like Eichhornia crassipes, Najas graminea, Nelumbo nucifera and Hydrilla verticellata were found to be the governing species on Site.

The maximum biomass $220.50 \mathrm{~g} / \mathrm{m}^{2}$ by Eichhornia crassipes was found during February. The minimum value was recorded in July i.e. $26.25 \mathrm{~g} / \mathrm{m}^{2}$, an increasing trend in biomass was noticed from month of September 2019 to February 2020. Najas graminea was the second most dominant species in this site, with highest biomass recoded in the month October i.e. $95.55 \mathrm{~g} / \mathrm{m}^{2}$, with an increasing trend from June to October. The lowest value was recorded in March $\left(25.20 \mathrm{~g} / \mathrm{m}^{2}\right)$. Species like Hydrilla verticellata showed maximum biomass in March $\left(43.20 \mathrm{~g} / \mathrm{m}^{2}\right)$ and minimum in August $\left(1.92 \mathrm{~g} / \mathrm{m}^{2}\right)$. Nelumbo nucifera was noted with highest biomass $82.83 \mathrm{~g} / \mathrm{m}^{2}$ in September and lowest in March i.e. $13.50 \mathrm{~g} / \mathrm{m}^{2}$. Species Nymphoides cristata and Nymphaea nouchali show maximum range of biomass in December $13.86 \mathrm{~g} / \mathrm{m}^{2}$ and $49.31 \mathrm{~g} / \mathrm{m}^{2}$. There minimum value was recorded in March 2.64 $\mathrm{g} / \mathrm{m}^{2}$ and $13.86 \mathrm{~g} / \mathrm{m}^{2}$. Ceretophyllum demersum and Alternathera philoxeriodes recorded $14.97 \mathrm{~g} / \mathrm{m} 2$ and $5.19 \mathrm{~g} / \mathrm{m}^{2}$ maximum in December and October. Potamageton nodosus, P. cripus, Chara fibrosa and Nechamandra alternifolia recorded their maximum biomass in range from $0.64 \mathrm{~g} / \mathrm{m}^{2}$ to $40.8 \mathrm{~g} / \mathrm{m}^{2}$. Other species reported a total biomass of $4.37 \mathrm{~g} / \mathrm{m}^{2}$

Monthly variation of biomass was observed; maximum was reported in the month of February, accounting $15 \%$ of the total biomass weighting $387.91 \mathrm{~g} / \mathrm{m}^{2}$ and lowest biomass was recorded in $123.27 \mathrm{~g} / \mathrm{m}^{2}$ in July.

The analytical data revealed that the dominant macrophytic species exhibited the peak biomass in different months during the study period. Sinha and Sahai (1970) and Shah and 
Abbas (1979) recorded maximum biomass for Eichhornia crassipes during the winter season, which was also noticed during study period.

In the present study, the maximum biomass contributors were the free-floating plants with $40 \%$ (1293.34), the submerged species hold $33 \%$ (1049.44) biomass, followed by rootedfloating leave $25 \%$ (816.58) and minimal reported by emergent type 2\% (74.99) on Site. Sahai and Sinha (1970) and Shah and Abbas (1978) reported that free floating macrophytes showed greater biomass as compared to the submerged ones. The values observed in the present study have been found lower than the values reported by Verma (1979) in Gujar lake, Jaunpur $(2616.86 \mathrm{~g} / \mathrm{m} 2$ from the emergent zone, $1446.80 \mathrm{~g} / \mathrm{m}^{2}$ from the floating zone and $1378.28 \mathrm{~g} / \mathrm{m}^{2}$ from the submerged zone). Singh (1983) also reported higher values of $1340.47 \mathrm{~g} / \mathrm{m}^{2}$ in littoral zone and $1403.91 \mathrm{~g} / \mathrm{m}^{2}$ in pelagic zone in Surha Tal lake, Singhal and Singh (1978) reported that pure stands of any macrophytic species had greater biomass compared to the stands of the mixed species. Likens (1973) and Westlake (1975) also reported high values of biomass for the submerged communities in the different climatic zones viz. temperate marsh community $\left(4600 \mathrm{~g} / \mathrm{m}^{2}\right)$ and tropical emergent communities $\left(3000\right.$ to $\left.5000 \mathrm{~g} / \mathrm{m}^{2}\right)$. In the temperate zones, the values of biomass for the emergent plants have been reported to range from 1.5 to $3.5 \mathrm{~kg} \mathrm{~m}^{2}$ for the aerial shoots (Boyd, 1969; Kvet, 1971; Szajnowski, 1973, Westlake, 1975). More or less equal amount of aerial biomass often exceeding $2.0 \mathrm{~kg} / \mathrm{m}^{2}$ have been observed for the emergent macrophytes of the tropical zones (Pearsall, 1959; Ogawa et al., 1961; Sinha, 1970; Ambasht, 1971; Kaul, 1977; Westlake, 1975). Devi (1993) also reported higher ranges of biomass values in Waithou Lake, Manipur (1305.76 $\mathrm{g} / \mathrm{m} 2$ for the first year and 1173.01 $\mathrm{g} / \mathrm{m} 2$ for the second year). Billore et al., (1998) also reported a higher range of biomass value of 1.7 to $2.7 \mathrm{~kg} / \mathrm{m}^{2}$ for the floating macrophytes in the Solasagar pond at Ujjain.

Reddy (1984) emphasized that the high accretion of biomass in Eichhornia crassipes was attributed to the dominance of the species over the other species throughout the year. Eichhornia crassipes beats other species with recording highest biomass $1293.26 \mathrm{~g} / \mathrm{m}^{2}$, the peak season of bloom was seen in winter season. The biomass ranged from $26.25 \mathrm{~g} / \mathrm{m}^{2}$ to $220.50 \mathrm{~g} / \mathrm{m}^{2}$. The present estimated biomass value for $E$. crassipes is very much the in range with work of Westlake who reported $1500 \mathrm{~g} / \mathrm{m}^{2}$ of $E$. crassipes biomass in Mississippi Lake, value reported by Singh was $908.4 \mathrm{~g} / \mathrm{m}^{2}$ in Surhatal lake, Balia. The values that were recorded for E. crassipes was found higher in the Waithou lake Shahai and Sinha $\left(720 \mathrm{~g} / \mathrm{m}^{2}\right)$ from Ramgarh lake in Gorakpur than those recorded from the Tankighat $\left(350.4 \mathrm{~g} / \mathrm{m}^{2}\right)$ and $449.6 \mathrm{~g} / \mathrm{m}^{2}$ from Tilokothighat of Bhagalpur Shah and Abbas. The highest biomass of the macrophylic species typically occurs in the northern hemisphere during the flowering cycle of July and August.' In the current analysis, the maximum biomass in the flowering month of February was shown by E. crassipes.

The present values of Hydrilla verticillata ranging from $43.20 \mathrm{~g} / \mathrm{m}^{2}$ and $1.92 \mathrm{~g} / \mathrm{m}^{2}$, with a total biomass of $221.24 \mathrm{~g} / \mathrm{m}^{2}$ Comparable values were also reported by Shah and Abbas (1979) in Bhagalpur (250.40-375.60 g/m²); Anand (1986) in Gadigarh stream, Jammu (206.29 g/ $\left.\mathrm{m}^{2}\right)$; Singh (1976) in Pantnagar $\left(180.40 \mathrm{~g} / \mathrm{m}^{2}\right)$; ); Singhal and Singh (1978) in Nainital (40.0-243.0 g/ $\mathrm{m}^{2}$ ); Durani and Rout (1982) in Nandan Kanan lake, Orissa (324.50 $\mathrm{g} / \mathrm{m}^{2}$ ); Gopal et al., (1978) in Jaipur (185.80 $418.30 \mathrm{~g} / \mathrm{m}^{2}$ Kaul et al., (1978) in Kashmir $\left(104-387 \mathrm{~g} / \mathrm{m}^{2}\right)$; Purohit and Singh (1987) in Nainital lake $\left(2.0-354.10 \mathrm{~g} / \mathrm{m}^{2}\right)$; Sinha and Sahai (1968) in Gorakhpur $\left(533.0 \mathrm{~g} / \mathrm{m}^{2}\right)$. 
Table.1 List of identified macrophytes in Manikamaun wetland

\begin{tabular}{|c|c|c|c|}
\hline $\begin{array}{l}\text { SI. } \\
\text { No }\end{array}$ & Scientific Name & Family & Habitat \\
\hline 1. & Nymphaea nouchali Burm.f. & Nymphaeaceae Salisb. & Rooted Floating \\
\hline 2. & Nelumbo nucifera Gaertn. & Nelumbonaceae Dunn. & Rooted Floating \\
\hline 3. & Nymphoides cristatum H. Hara & $\begin{array}{l}\text { Menyanthaceae } \\
\text { Sequier. }\end{array}$ & Rooted Floating \\
\hline 4. & Ipomoea aquatic Forssk & Convolvulaceae Juss. & Emergent \\
\hline 5. & Bacopa monnieri (L.) Pennell & Scrophulariaceae Juss. & Emergent \\
\hline 6. & $\begin{array}{c}\text { Alternanthera philoxeroides (Mart.) } \\
\text { Griseb }\end{array}$ & Amaranthaceae Juss. & Emergent \\
\hline 7. & Ceratophyllum demersum L. & $\begin{array}{l}\text { Ceratophyllaceae S. F. } \\
\text { Gray }\end{array}$ & Submerged \\
\hline 8. & Azolla pinnata $\mathrm{R} . \mathrm{Br}$. & Salviniaceae Martinov & Free Floating \\
\hline 9. & $\begin{array}{l}\text { Hydrilla verticillata (L. f.) } \\
\text { Royle }\end{array}$ & Hydrocharitaceae Juss & Submerged \\
\hline 10. & $\begin{array}{l}\text { Nechamandra alternifolia } \\
\text { (Roxb. Exwight) Thwaites }\end{array}$ & Hydrocharitaceae Juss & Submerged \\
\hline 11. & Vallisneria spiralis L. & Hydrocharitaceae Juss & Submerged \\
\hline 12. & $\begin{array}{c}\text { Eichhornia crassipes } \\
\text { (Mart. ) Solms }\end{array}$ & Pontederiaceae Kunth & Free Floating \\
\hline 13. & $\begin{array}{l}\text { Colocasia esculenta (L. ) } \\
\text { Schott. }\end{array}$ & Araceae Juss. & Emergent \\
\hline 14. & $\begin{array}{l}\text { Spirodela intermedia } \mathrm{W} . \\
\text { Koch }\end{array}$ & Lemnaceae S. F. Gray & Free Floating \\
\hline 15. & Potamogeton crispus L. & Potamogetonacea Dum & Submerged \\
\hline 16. & Potamogeton nodosus Poiret & Potamogetonacea Dum & Submerged \\
\hline 17. & Najas graminea Del. & Najadaceae Juss. & Submerged \\
\hline 18. & Cyperus imbricatus L. & Cyperaceae Juss. & Emergent \\
\hline 19. & Cyperus compressus L & Cyperaceae Juss. & Emergent \\
\hline 20. & Cynodon dactylon (L.) Pers. & Poaceae Barmhart. & Emergent \\
\hline 21. & $\begin{array}{l}\text { Cortaderia selloana Schult. } \\
\text { \& Schult.f.) Asch. \& Graebn. }\end{array}$ & Poaceae Barmhart. & Emergent \\
\hline 22. & $\begin{array}{l}\text { Glyceria maxima } \\
\text { (Hartm.) Holmb. }\end{array}$ & Poaceae Barmhart. & Emergent \\
\hline 23. & Marsilea minuta $\mathrm{L}$ & Marsileaceae Mirab. . & Rooted Floating \\
\hline 24. & Chara fibrosa Ag. ex Buz. & Characeae R. D. Wood & Submerged \\
\hline
\end{tabular}


Table.2 Range and Total biomass $\left(\mathrm{g} / \mathrm{m}^{2}\right)$ of different macrophytes species of Manikamaun wetland

\begin{tabular}{|l|c|c|c|}
\hline \multicolumn{1}{|c|}{ Name of Species } & \multicolumn{2}{|c|}{$\begin{array}{c}\text { Range } \\
\text { (entire range) }\end{array}$} & $\begin{array}{c}\text { Total Biomass } \\
\left(\mathbf{g} / \mathbf{m}^{\mathbf{2}}\right)\end{array}$ \\
\hline Eichhornia crassipes & 220.5 & 26.25 & 1293.26 \\
\hline Najas graminea & 95.55 & 25.2 & 610.17 \\
\hline Nelumbo nucifera & 82.83 & 13.5 & 562.75 \\
\hline Hydrilla verticellata & 43.2 & 1.92 & 221.24 \\
\hline Nymphaea nouchali & 49.31 & 22.4 & 179.32 \\
\hline Potamageton nodosus & 40.8 & 6.13 & 126.02 \\
\hline Nymphoides cristata & 13.86 & 2.64 & 71.31 \\
\hline Ceretophyllum demersum & 14.97 & 3.74 & 62.7 \\
\hline Alternanthera philoxeroides & 5.19 & 1.8 & 41.41 \\
\hline Colocasia esculenta & 5.82 & 1.51 & 21.86 \\
\hline Potamageton cripus & 4.95 & 0.88 & 14.29 \\
\hline Ipomoea aquatic & 2.4 & 0.24 & 7.44 \\
\hline Vallisneria spiralis & 1.36 & 0.54 & 5.8 \\
\hline Nechamandra alternifolia & 1.4 & 0.16 & 5.2 \\
\hline Chara fibrosa & 0.64 & 0.36 & 4.02 \\
\hline Marsilea quadrifolia & 0.75 & 0.15 & 3.2 \\
\hline Other species & 0.48 & 0.02 & 4.371 \\
\hline All species combined & 387.91 & 123.27 & 2796.07 \\
\hline
\end{tabular}

Fig.1 Percentage contribution from different types of macrophytes

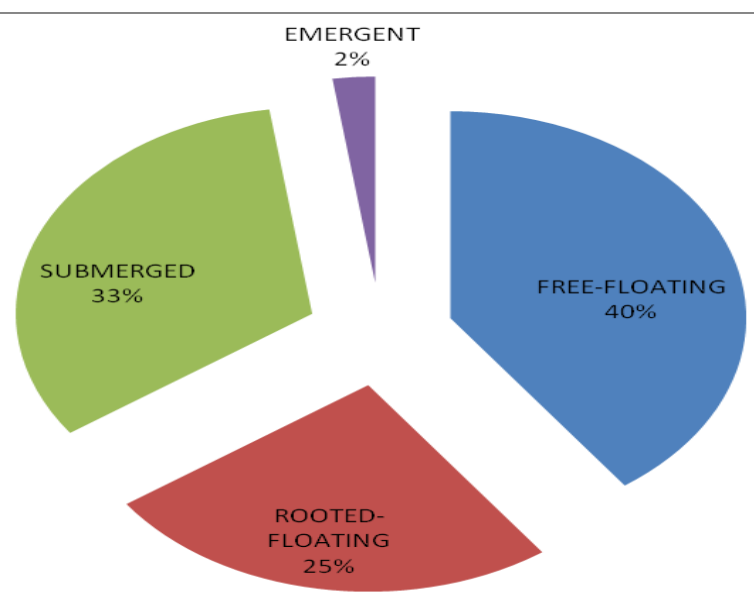


Fig.2 Monthly biomass variation of Aquatic macrophytes in manikmaun

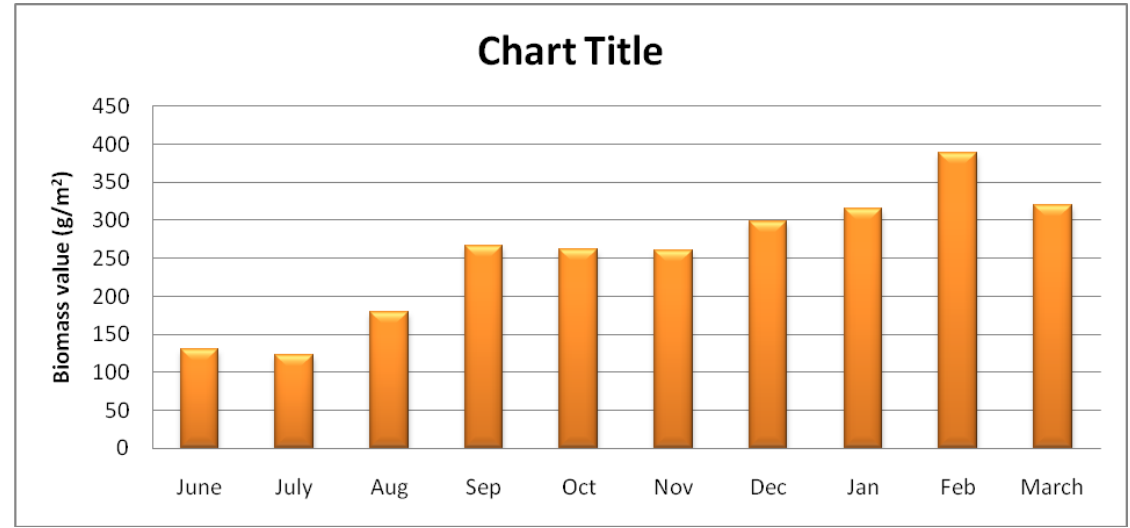

Fig.3 Location map of study site

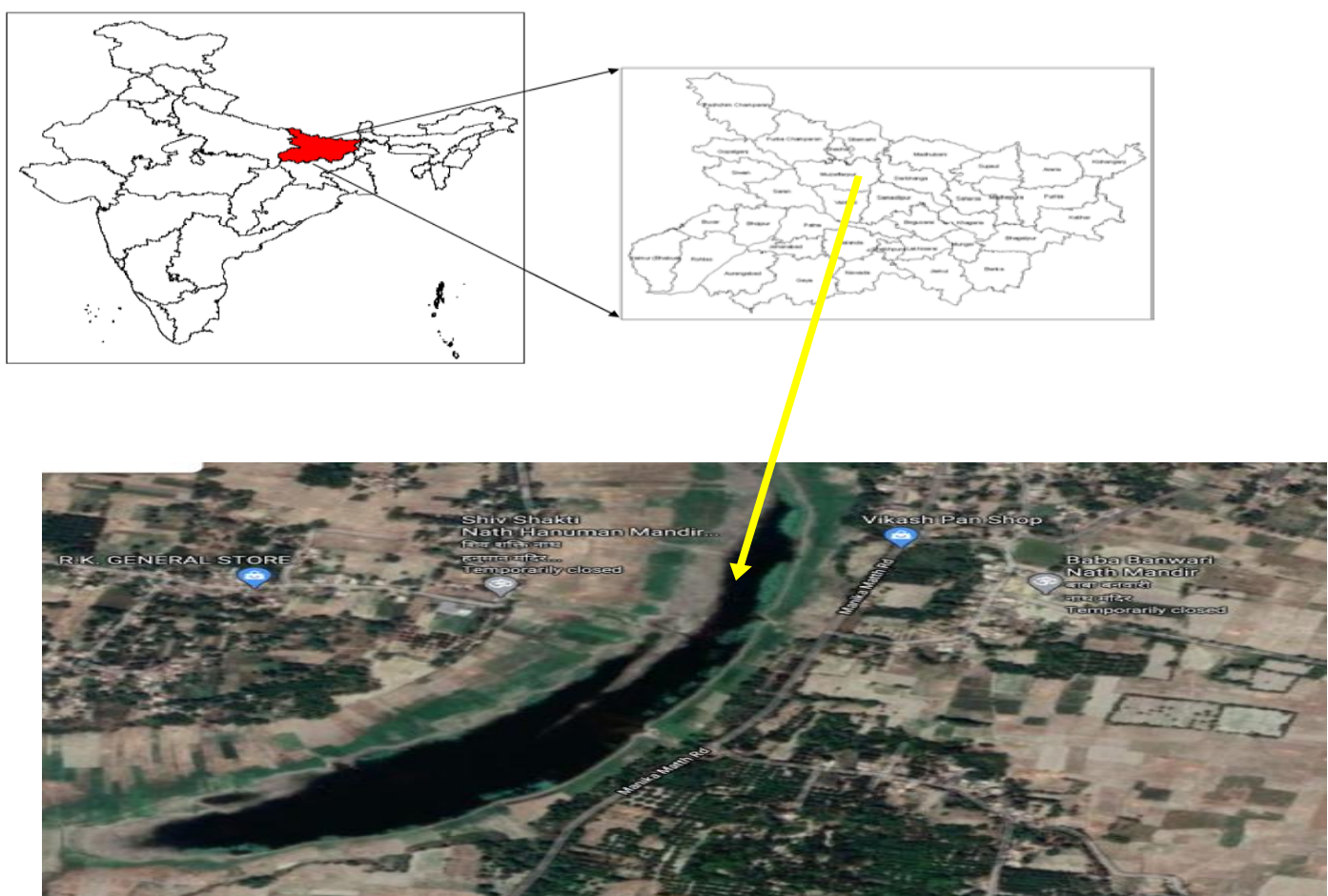

In Nelumbo nucifera, the peak biomass was recorded to be $13.50-82.83 \mathrm{~g} / \mathrm{m}^{2}$. The present estimated values are found to be higher than those recorded by Billore and Vyas (1982) in Lake Pichhola, Udaipur (5.0 to $25.0 \mathrm{~g} / \mathrm{m}^{2}$ ), Ambasht and Ram (1976) in Varanasi $\left(63.20 \mathrm{~g} / \mathrm{m}^{2}\right)$, Devi, K.L (1998) in Lake Utrapat, Manipur (20.82 - $\left.66.96 \mathrm{~g} / \mathrm{m}^{2}\right)$. The present results were found to be lower than the values recorded in Pantnagar (700.0 $\mathrm{g} / \mathrm{m}^{2}$ ) and Kaul et al., (1978) in Anchar lake, Kashmir $\left(549.0-813.0 \mathrm{~g} / \mathrm{m}^{2}\right)$ by Singh (1976), Devi, O.I (1993) in Lake Waithou, Manipur $\left(95.28 \mathrm{~g} / \mathrm{m}^{2}\right.$ and $104.30 \mathrm{~g} / \mathrm{m}^{2}$ for the first and second years respectively)

In the present study, the total biomass for Nymphoides cristatum 13.86 and $2.64 \mathrm{~g} / \mathrm{m}^{2}$ on 
Site. The present values have been found lower than the value reported by Devi, O.I. (1993) $\mathrm{n}$ the waithou lake $\left(47.04 \mathrm{~g} / \mathrm{m}^{2}\right.$ and $51.98 \mathrm{~g} / \mathrm{m}^{2}$ in the first and second year respectively) and Devi, K.I. (1998) in utrapat lake ( 7.66 to $\left.50.13 \mathrm{~g} / \mathrm{m}^{2}\right)$

In the present study the total biomass recorded was $2541.88 \mathrm{~g} / \mathrm{m}^{2}$. Values of biomass higher than those in the present study were also reported by various workers. Kaul (1977), Vass (1980), Zutshi and Vass (1982) and Kaul and Handoo (1989) through intensive investigations of the lakes in Kashmir reported the biomass range of 9 to 150 tons $/ \mathrm{ha}^{-1}$ for the macrophytes. Ambasht (1971) reported higher aboveground biomass for the emergent species $\left(1250 \mathrm{~g} / \mathrm{m}^{2}\right)$ in a fish pond at Varanasi. The maximum values in the present study have also been found higher than the values reported by Crowder et al., (1977) $\left(1154.00 \mathrm{~g} / \mathrm{m}^{2}\right)$ in Opinicon lake and Howard-Williams et al., 1986, (1106.00 g/m²) in lake. Waikaremoana. Ballia. The biomass values of 50 to $100 \mathrm{~g} / \mathrm{m}^{2}$ and 630 to 4640 $\mathrm{g} / \mathrm{m}^{2}$ were recorded in the lakes of New Zealand and the reed swamps in Minnesota, USA (Sculthorpe, 1967). In a study of five lakes of Udaipur, Vyas et al., (1989) reported 537.6 to $1884.09 \mathrm{~g} / \mathrm{m}^{2}$ of biomass for the macrophytes which have been found to be much higher than the reported values in the present study.

In the present investigation, it is evident that the maximum biomass was contributed by the free floating and the submerged species. The emergent species contributed the least number of species. The findings are in conformity with the studies made by Shah and Abbas (1979), Forsberg (1959) and Sahai and Sinha (1970). They reported that free-floating macrophytes showed greater biomass as compared to the submerged ones. Singhal and Singh (1978) were of the view that pure stands of any macrophytic species had greater biomass compared to the stands of the mixed species. Pearsall (1930) also emphasised on the productive nature of the emergents because they have the best of both the submerged and terrestrial habitats, in as much as gaseous exchange of $\mathrm{CO}_{2}$ and direct sunlight are concerned. Westlake (1963) while reviewing the available ecological data pertaining to the productivity of the different plant communities, pointed out that the submerged freshwater communities are strikingly less productive than the emergent communities.

The macrophytic production is found related to the depth gradients and in some Indian lakes, emergent forms have recorded maximum production in shallower depths while higher productions of floating and rooted floating leaved species have been observed in deeper habitats (Handoo, 1978; Hando and Kaul, 1982; Kaul et al., 1978; Kaul and Handoo, 1989; Vyas et al, 1989). The variations in the macrophytic productions have got close relationships with the physicochemical characteristics of the various physiographic factors. Though any definite relationship between soil type and species distribution could not be established by Spence (1967a) in Scotland, yet Kaul et al., (1982) observed dense growth of submerged species on the organic matter rich sediments of Dal lake in Kashmir. Moss (1989) also opined that the contributions made by the aquatic plants should be greater in shallowly sloping basins than in the steep sided ones. The relationship between the area extent of the distribution of the emergent and floating leaved species with the physico-chemical parameters of the lake has been so emphasized that the area coverage of the macrophytes have been predicted in the Swedish lakes by regression equations using parameters like relative area, total nitrogen content and water depth etc. (Moss, 1989). 
In conclusion the seasonal fluctuation was observed in the biomass values throughout the research periods on Manikamaun wetland. Recorded biomass values of reported macrophytes were compared to the significant similar work done in state of Bihar, and also to other states and abroad. From the work done on the wetlands, reflects the condition of eutrophication prevailing in the water body, with very less management of the wetlands. As the water body fulfill the needs of local people and others as well initiative should be taken for the proper handling of these wetlands.

\section{Acknowledgement}

Authors are thankful to Dr Adita Sharma, (Fisheries Resource Management) Ph. D., Assistant Professor and Dr S. C. Rai, Dean, College of Fisheries, Dr. Rajendra Prasad Central Agricultural University, Dholi, Muzaffarpur, Bihar, India.

\section{References}

Acharjee, S., \& Sarma, J. N. (2012). A study of wetlands and their role in geoecological environment of the Bhogdoi basin, Jorhat, Assam, using remote sensing and GIS. International Journal of Physical and Social Sciences, 2(10), 310-323

Ambasht, R.S. (1971). Ecosystem study of a tropical pond in relation to primary production of different vegetational zones. Hydrobiologia, 12: 57-61.

Ambasht, R.S. and K. Ram (1976). Stratified primary productive structure of certain macrophytic weeds in a large Indian lake. pp. 147-176. In: C.K.. Varshney and J. Rzoska (Eds). Aquatic weeds in South East Asia. Dr. W. Junk, Hague.

Anand, V.K. (1986). Productivity study of Hydrilla verticillata (L.f.) Royle in Gadigarh stream, Jammu. J. Ecol. 13(2): 329-333.
Billore, D.K. and L.N. Vyas (1982). Distribution and Production of Macrophytes in Pichhola Lake, Udaipur (India), pp. 45-54. In: B. Gopal, R.E. Turner, R.G. Wetzel and D.F. Whigham (Eds). Wetlands Ecology and Management. National Institute of Ecology and International Scientific Publications, India.

Billore, S.K.; R. Bhardia and A. Kumar (1998). Potential removal of particulate matter and nitrogen through roots of water hyacinth in a tropical natural wetland. Current Science 74(2): 152-156.

Boyd, C.E. (1969). Production, mineral nutrient absorption and biochemical assimilation by Justicia americana and Altemanthera philoxeroides. Arch. Hydrobiol. 66:139160.

Cook, C. D. (1996). Aquatic and wetland plants of India. Oxford University Press.

Crowder, A.A.; J.M. Bristow; M.R. King and S. Vandcrkloct (1977). Distribution, seasonality and biomass of aquatic macrophytes in Lake Opinicon. Naturaliste Can. 104:441-456.

Devi, 0. Ibeton (1993). Distribution, primary production and nutrient status of the macrophytic communities in Waithou lake, Manipur. Ph.D. Thesis, Manipur University, Manipur.

Devi, K. Indira (1998): Ecological studies of freshwater macrophytes in Utrapat lake, Manipur. Ph.D. Thesis, Manipur University, Manipur.

Devi, K. Indira and B.M. Sharma (1997). Growth form analysis of the macrophytes of Utrapat lake, Manipur. Proc. Right Manipur Science Congress, Manipur University, pp. 22-30. (linv.).

Durani, P.K. and D.K. Rout (1982). Phytosociology and production ecology of Nandan Kanan lake in Orissa Geobios. 9:25-29.

Gopal, B. (1968). Distribution and Ecology of Indian Species of Marsilea. Ph.D. Thesis, 
Banaras Hindu University, Varanasi.

Gopal, B. and Sharma, K.P. (1978a). Studies on wetlands in India with emphasis on structure, primary production and management. Paper for wetland symposium. Ilnd. Int. Cong, of Ecology. Jerusalem, Israel.

Heegaard, E., Birks, H. H., Gibson, C. E., Smith, S. J., \& Wolfe-Murphy, S. (2001). Species-environmental relationships of aquatic macrophytes in Northern Ireland. Aquatic botany, 70(3), 175-223.

Houghton RA (2005) Aboveground forest biomass and the global carbon balance. Global Change Biology 11: 945-958.

Howard-Williams, C.; J. Davis and W.F. Vincenl(1986). Horizontal and vertical variability in the distribution of aquatic macrophytes in Lake Waikaremona. New Zealand Journal of Murine ami Fieshwtci Rcsciucli 20; 55-65.

Kaul, V. (1977). Limnological survey of Kashmir lakes with reference to trophic status and conservation. Int. J. Ecol. Environ. Sci. 3:29-44.

Kaul, V. and D.P. Zutshi (1967). A study of aquatic marshland vegetation in Srinagar. Proc. Nat. Inst. Sci. India, 33:111-127.

Kaul, V. and J.K. Handoo (1982). Water characteristics of some freshwater bodies of Kashmir. Current trends in Life Sciences. 9:221-246.

Kaul, V. and J.K. Handoo (1989). Studies on the ecology of Kashmir, Himalaya pp. 149. In: J.S. Singh and B. Gopal (Eds.). Perspectives in Ecology. Jagmander Book Agency, New Delhi.

Kaul, V., C.L. Trisal and J.K. Handoo (1978). Distribution and production of macrophytes in some water bodies of Kashmir. pp.313-334. In: J.S. Singh and B. Gopal (Eds). Glimpses of Ecology. Int. Sci. Pubis., Jaipur.

Keddy, P. and Fraser, L. H. (2000). Four general principles for the management and conservation of wetlands in large lakes: the role of water levels, nutrients, competitive hierarchies and centrifugal organization. Lakes \& Reservoirs: Research \& Management, 5(3), 177-185.

Kumari, P., and Jha, M. M. Diversity, Density \& Nutrient lock up efficiency of Macrophytes in a Wetland of N. Bihar.

Kvet J. (1971): Growth analysis approach to the production ecology of reed swamp plant communities. Hydrobiologia. 25:119-137.

Likens, G. E. (1973). Primary production: Freshwater ecosystems. Human Ecology. 1(4):347- 356.

Moss, B.(1989). Ecology of freshwaters. Man and Medium. Blackwell Scientific Publication, Oxford.

Moyle, J.B. (1945), Some chemical factors influencing the distribution of aquatic plants in Minnesota. American Midland Naturalist, 34:402-420.

Ogawa, M.; K. Yoda and T. Kira (1961). A preliminary survey on the vegetation of Thailand. Nat. life. S.E. Asia 1: 21-157.

Pathak V, Tyagi RK, Singh B (2004) Ecological status and production dynamics of wetlands of Uttar Pradesh. Central Inland Capture Fisheries Institute, Barrackpore

Peakall, D., \& Burger, J. (2003). Methodologies for assessing exposure to metals: speciation, bioavailability of metals, and ecological host factors. Ecotoxicology and Environmental Safety, 56(1), 110121.

Pearsall W.H. (1930). Phytoplankton in the English Lakes. I. The proportion in the water of some dissolved substances of biological importance. J. Ecol. 18:306320.

Purohit, R. and S.P. Singh (1987). Niche response surfaces and productivity estimates of macrophytes in Lake Nainital, Central Himalaya, India. Aquat. Bot. 29:49-62.

Reddy, K.R. (1984). Water hyacinth (Eichhomia crassipes) biomass 
production in Florida. Biomass 6:167181.

Sahai, R. and A. B. Sinha (1968). A supplement to the aquatic and swampy vegetation of Gorakhpur, Indian Forester. 94(11):819821.

Sahai, R. and A. B. Sinha (1970a). Contribution to the ecology of Indian Aquatics-1. Seasonal changes in Biomass of water hyacinth (Eichhomia crassipes (Mart) Solms). Hydrobiol. 35(3-4):378382.

Sahai, R. and A. B. Sinha, (1969b). Investigations on bioecology of inland waters of Gorakhpur (U. P.) India I. Limnology o f Ramgarh lake. Hydrobiologia 34:433-447.

Sahai, R. and A.B. Sinha (1970b). Idem II. Studies on the productivity of duckweeds (Lemna minor L. and Spirodela polyrhiza (L) Schleid). Proc. 57th Sess. Ind. Sci. Congr. Under Symposium Plant Productivity Studies in India 10.

Shah, J.D. and S. G. Abbas (1979). Seasonal variation in Frequency, Density, Biomass and rate of production of some aquatic macrophytes of the River Ganges at Bhagalpur (Bihar). Torp. Ecol. 20(2): 127-134.

Singhal, P.K. and J. S, Singh (1978). Ecology o f Nainital Lakes: Morphometry and macrophytic vegetation. Trop. Ecol. 19(2): 178-188.

Spence (1967), D.H.N. (1\%7). Factor controlling the distribution of freshwater macrophytes with particular reference to the lochs of Scotland. J. Ecol. 55:147170.

Szajnowski F. (1973). The relation between the leaf area and production of aboveground parts of common reed (Phragmites communis Trin) Pol. Arch. Hydrobiol. 20:157-8.

Vass, K.K. (1980). On trophic status and conservation o f Kashmir lakes. Hydrobiologia 68(1):9-15.

Verma, K.R. (1979). Phytosociology, productivity and energetics of macrophytes of Gujar lake (Khetasarai) Jaunpur. Ph.D.d Thesis, Banaras Hindu University, Varanasi.

Vyas, L.N.; S.K. Sankhla and P.P. Paliwal (1989). Hydrobiological studies o f Udaipur lakes. pp. 389-411. InJf.S. Singh and B. Gopal (Eds). Perspectives in ecology/Jagmander Book Agency, New Delhi

Westlake, D.F. (1963). Comparison of plant productivity. Bot. Rev. 28: 385-425.

Westlake, D.F. (1975). Primary production of freshwater macrophytes. Part II Primary production in aquatic ecosystems, pp. 189-206. In: J.P. Cooper (Eds.) Photosynthesis and Productivity in Different Environments. Cambridge Press.Cambridge.

Zutshi, D.P. and K.K. Vass (1982). Limnological studies on Dal Lake, Srinagar, n. Biological features Proc. Indian Natu. Sci. Acad. 48(2): 234-241.

\section{How to cite this article:}

Priyanka Gautam, Adita Sharma, Poonam Prakash and Shivani Pathak. 2021. Macrophyte Diversity and Biomass Productivity of Manikamaun Wetland, Muzaffarpur, North Bihar. Int.J.Curr.Microbiol.App.Sci. 10(02): 2827-2837. doi: https://doi.org/10.20546/ijcmas.2021.1002.314 